\author{
Kristina Vorontsova \\ Department of English Literature and Culture, \\ Institute of Linguistics and Literary Studies, \\ Faculty of Humanities, \\ University of Natural Sciences and Humanities in Siedlce \\ Siedlce \\ https://orcid.org/0000-0001-9230-1043 \\ kristina.vorontsova@uph.edu.pl
}

\title{
Poland as a Great Borderland in the Post-Soviet World: Poetical Point of View
}

\begin{abstract}
This paper seeks to examine the characteristics of the literary space of Poland, which occupied a middle position between the West and the USSR, with particular attention to the mechanisms of representation of Poland as a great borderland in light of the catastrophes of the 20th century. Since the dissolution of the Soviet Union, narratives have changed but the main concept of "Poland as a Great Borderland" still remains. While absorbing traditional elements, poetry in the post-Soviet world uses new tools like "camp" to depict the liminality and carnival nature of the country. Alexander Anashevich's poems are analysed as a vivid example of contemporary perceptions of this centuries-long intercultural practice.

Keywords: Poland, poetry, border studies, Great Border, Alexander Anashevich, postmodern, transgression, camp, queer studies.

This is an Open Access article distributed under the terms of the Creative Commons Attribution 3.0 PL License (creativecommons.org/licenses/by/3.0/pl/), which permits redistribution, commercial and non-commercial, provided that the article is properly cited. () The Author(s), 2019.

Publisher: Institute of Slavic Studies, Polish Academy of Sciences

Editor-in-chief: Jolanta Sujecka

Conception and academic editing of this issue: Katarzyna Roman-Rawska, Tomasz Rawski
\end{abstract}




\section{Introduction}

Dolitical relations between Poland and Russia/USSR, even after Poland's announcement of independence, were too often tense and troubled, and this influenced cultural relations and relations between the educated communities of both countries. However, in the second part of the 20th century, after the Khrushchev Thaw, Poland itself started playing a substantial role in both official Soviet culture and society and the underground dissident movement: it became a sort of a distinctive mediator between Soviet and world society and culture, affecting "the poetics of the generation" of the 1960s and the descriptive language of discussions on the internal problems of the USSR.

According to Irina Adelgeim, the Soviet intelligentsia suffered from a kind of "Polonomania" (Adel'geĭm, 2008, p. 253) during that period of time. Russian and American poet and essayist Joseph Brodsky explained this influence of Poland with its specific liminal position on the cultural map: on the one hand, the country was geographically and mentally understandable and close to the Soviet people, while on the other, it was a cultural resource they hadn't been able to use earlier, a window to Europe and the world (Brodski1, 2000, p. 602). Poles seemed the only real Europeans, so that another Soviet poet, David Samoylov, called Poland the "closest station of European civilization" (Samollov, 2000, p. 277).

Polish language and Polish magazines were considered to be a passport to literature banned in the USSR, such as books by William Faulkner, Albert Camus, George Orwell, James Joyce, Marcel Proust etc. The Soviet intelligentsia hence learned Polish and read in "Czytelnik" everything that was published in the Polish People's Republic to which they didn't have access in Russian. Not only was there a real national obsession with Polish theatres, music, and films by Andrzej Wajda, but also with more prosaic things, such as Polish women's fashion magazines, cosmetics, and clothes.

All these links, even tiny elements of the whole picture, led Professor Vladimir Kagansky to compare Poland for the Soviet generations of the 1960s and 1970s with a nature reserve, a European reserve in the Socialist Bloc (Kaganski1̆, 2018). Developing this metaphor further, it should be said that Poland preserved European values but also, however, "domesticated" them, translating them into common language and promoting cultural variety, as is usual in liminal territories. 


\section{Poland as a Great Borderland}

In terms of imaginative geography, Poland can be defined as a so-called "Great Borderland" (Dashkevich, 1989; Zamiatin, 2003, p. 107), a country whose main historical role is to unite cultures and nations. Being a boundary, a threshold, a neutral zone is considered to be a key characteristic of the Polish space in Russian culture, which has determined the narrative of the entirety of cultural relations between them for many centuries. Soviet art, especially literature, was attracted by the characteristics of the literary space of a country that a priori occupied an intermediate geoposition. Poland was a popular setting and trigger for discussing relevant internal problems of the USSR for many authors with extremely different points of view on politics, history and the role of art. The country was depicted in poems by the notorious anti-Semite and Polonophobe Stanislav Kunyev as well as in the writings of crucial figures of the Leningrad cultural underground such as Elena Shvarts and Viktor Krivulin, in songs by Bulat Okudzhava, Vladimir Vysotsky, Alexander Galich, in the creative work of official members of the Union of Soviet Writers, etc. Analysis of these texts reveals a wide range of creative freedom in a period of total censorship, ideological control and ethnic stereotypes, arising out of many decades of intercultural dialogue, and relatively stable sympathy towards Poland.

Notwithstanding differences in understanding the role of art in PolishRussian relations and, moreover, in official attitudes towards Soviet foreign and domestic policy, some common mechanisms of representation of Poland as a borderland can be mentioned: Poland as a front line, Poland as a cemetery, Poland as a mythopoeic threshold between various types of spaces, and Poland in a frame (Vorontsova, 2016). As a huge borderland due to the catastrophes of the 20th century, the country came to be associated with personal traumatic experience and personal changes resulting from transgression - whether physical, geographical, or cultural. In art, Poland as a real "in-between" space changed its characteristics, evolved, acquired new properties, became a territory of game and myth. Having become a Great Borderland due to the disasters of the 20th century, it has repeatedly been a functional field for existential experiences because of its marginality: man in war, man in concentration camp, man in emigration, and so on. Examples of this perception can easily be found in Soviet literature; however, after the dissolution of the USSR and the end of the "Iron Curtain", Poland rapidly lost its value to former Soviet citizens, together with its role of mediator. One of the possible explanations could be found in the changed position of Ukraine between Russia and the EU in the 2000s. It seems much more complicated 
now because of political agendas but, generally speaking, Ukrainian cultural life (especially contemporary Ukrainian poetry) has replaced the Polish in its importance (Kuzmin, 2007; Zorin, 2006).

Is it still possible to identify remains of Soviet narratives about the country in Russian literature?

\section{Current Situation}

When it comes to Poland in the Russian-speaking post-Soviet world, it would be fair to point out that the country has almost disappeared from all mental maps and social media. References are rare and untypical. In today's Russia, people hardly know anything about Polish culture and literature. According to a survey organized in 2014 by the Polish-Russian Centre for Dialogue and Understanding, $43 \%$ of respondents believe that the Poles are negatively disposed towards Russia and the Russians, while $92 \%$ of them have never been to Poland, and $89 \%$ have neither acquaintances nor relatives among the Poles (Polska-Rosja, 2015, p. 37). Modern sources of information about the inhabitants of the neighbouring country are limited to memories of older family members, political news about the relations between official Warsaw and Moscow, as well as consumer "household" knowledge. For 12\% of those surveyed, Poland today is apples, sausages, cosmetics and clothing (Polska-Rosja, 2015, p. 35), while tourism, literature and cultural contacts play absolutely no role in shaping the image of the country.

During the early 1990s there were still traces of the previous Polonomania and some new key moments like the ironic detective stories by Joanna Chmielewska, who was more famous and successful in the Russian book market than in Poland. Currently, average knowledge about Polish culture in modern Russia is limited to the series of fantasy books The Witcher by Andrzej Sapkowski and the eponymous computer game. Generally speaking, after several decades of cult status for homo sovieticus, the image of Poland has practically faded away from the consciousness of common people and has no impact on literature and art at all.

\section{Carnival becomes Camp}

The poet Alexander Anashevich (real name Alexander Yakovlev), hardly a trivial figure, seems one of a few exceptions in this situation. Mentions of the Polish literary space are relatively frequent in his poems, although grotesque and eccentric.

For sure, it is still possible to meet images of Poland in a creative work by Belarusian-writing or Ukrainian-writing poets (e.g. Serhiy Zhadan's 
Warsaw, 1995 [Varshava]; Polish Rock [Pol's'kij rok]), or Russian-speaking poets of Ukraine and Latvia. But this is considered to have almost nothing in common with the previous admiration that took place in the Soviet Union. For instance, Boris Khersonsky, who is supposed to be a crucial figure of contemporary Russian-speaking Ukrainian poetry, recreates Poland as a setting of his epic book Family Archive, 1996-2003 [Semejnyj arhiv], but he focuses on the Galicia region, which was a part of the Austro-Hungarian Empire at the beginning of the 20th century, a very specific area associated with Jewish culture. The poet vividly depicts a family chronicle through all the tragedies experienced by Jews and it is considered to be a "Jewish text" rather than "Polish".

When it comes to Russian-speaking poets who are particularly interested in Polish culture, as a rule they do not live in Russia: prominent examples include Sergei Moreino (lives in Riga) and Igor Belov (lives in Warsaw). Both of them rebuild the cultural and artistic space of Poland in details, they are familiar with the geography of the country, its history and art, and they are known as leading translators of Polish poetry.

The originality of Alexander Anashevich and his image of Poland could be seen in the fact that he lives in provincial Russia and has no private links to Polish culture. He was born in Voronezh in 1971 and belonged to the socalled "Vavilon generation"1 of poets who specialized in free verse. Most of Anashevich's mature creative work appeared after the collapse of the Soviet Union and could be considered a vivid example of all the new tendencies in understanding the specific role of Poland in the post-Soviet cultural space. It should be mentioned that Anashevich is not only a poet but also writes comic plays. His aesthetics and poetics are based on the folkloric carnival theatre of medieval marketplaces, with its roots in buffoonery and farce. Anashevich follows the scheme of free "Rayok" verses traditional for Russian folk performances, principally avoiding accurate rhymes and orderliness (Orlitskili, 2017, p. 165).

Anashevich has published several books of poems (So Many Traps, 1997 [Stol'ko lovushek]; Siren Signals, 1999 [Signaly sireny]; Unpleasant Film, 2001 [Nepriyatnoe kino]; Fragments of the Kingdom, 2002 [Fragmenty korolevstva]; Birds, Butterflies, Dead Girls, 2012 [Ptichki, babochki, mertvyachki]; Word Order, 2012 [Poryadok slov]), short stories (Cock, 2001

1 Vavilon was a famous independent literary magazine published from 1993 till the 2000s by Dmitry Kuzmin, a founder of the Agro-Risk publishing house. His second magazine Risk was supposed to be mostly a gay literary journal focusing on contemporary culture. Alexander Anashevich belonged to the community of authors who wrote for both magazines before they came to an end. It is quite interesting that Russian scholars and critics attempt to avoid the connection between the poet and the LGBT movement, while abroad it is a common link. 
[Huj]; Alla Pugacheva's Died, 2002 [Alla Pugacheva umerla]) and plays (Butt of Happiness, 1996 [Popa schast'ya], Girls, 1995 [Devushki]; Lisa's Dancing [Liza tancuet]; Pins, 2006 [Bulavki]) etc. Twice (in 1999 and 2001) Anashevich was nominated for the Andrei Bely Prize, the most prestigious independent award in literary Russia. His writing has been partly translated into English by Rebecca Bella and Vitaly Chernetsky and has drawn critics' attention all over the world.

Although Poland is said to be an absolutely forgotten land for post-Soviet poets, Anashevich is similar to his predecessors and uses the literary space of the country as a backdrop for poetical mini-plays and a functional field for lyrical plot and character development. On the one hand, the author is definitely innovative in his choice of images of Poland and creation of a lyrical subject. On the other hand, his perception of the country refers to Soviet in-depth samples and narratives, somewhat changed but still influential and recognizable.

Firstly, as noted earlier, liminal Poland could be described as the front line between two armies. While in Soviet poetry this concept corresponded to the tragic events that took place in reality during WWII, Anashevich, in contrast, focuses on an unreal generalized "Great War" in the middle of Europe. His characters are "puppets" from street theatre, so this fighting can be interpreted as a game with toy soldiers ${ }^{2}$, but extremely tragic and traumatic, and those soldiers (together with clowns) are repetitive images in the texts being analysed ${ }^{3}$ :

Only would it not be cold to a clown and a soldier. Those haughty guys, lecherous brothers.

... Only would it not be cold to them, only would it not be hot to them with a Polish bullet in the forehead. (Anashevich, 1997, p. 21)

The poet plays with the interrelation between different meanings of the notion of "theatre" - as a place for performances by actors and an area for important military operations. And, as we saw earlier, in his poems Poland is the most appropriate territory because its history combines both.

Next, there is the issue of topographical concreteness for such a conditional theatrical space. The clown and the soldier, for instance, "are

\footnotetext{
2 It seems obvious that these soldiers are closer to the main character of the fairy tale The Steadfast Tin Soldier by Hans Christian Andersen than to socialist realistic fighters. They don't obey death, appear again and again in different texts about Poland, are almost unstoppable with bullets, and, of course, some "paper ballerinas" are involved - Anashevich depicts a variety of tender female images.

3 All Anashkevich's poems, except I Heard: An Actor from the Burnt-Down Theatre [Ya slyshal: akter pogorelogo teatra], have been translated by the author of this paper.
} 
crossing lands between Poznań and Kraków” (Anashevich, 1997, p. 21), almost the whole of Poland from the north-west to the south-east. It should be mentioned that these cities were not as common in Soviet poetry as Warsaw or Auschwitz. They existed in a fragmentary fashion, but as symbols of specific events (the Poznań protest of 1956; the liberation of Kraków from the Nazis by Ivan Konev, etc.). Certainly the iconic Kraków Trumpeter and St. Mary's Church bugle call also have a place in Soviet poetry, from Bulat Okudzhava's prominent Farewell to Poland, 1966 [Proschanie s Pol'shej] to Genrikh Sapgir's Returning to Itaka, 1970-1974 [Vozvrashcenie v Ita$\mathrm{ku}$. Anashevich in turn ignores this tradition, his Kraków is completely different. We see an ironic attempt to create a credible literary space for incredible events and characters. The lyrical hero of another poem without a title highlights the same topographical limits for his story: "I'm lying between Poznan and Kraków, there is an Arab and a Persian at each pillar. / Composing a gloomy song, they'll bring my play to the finale, bring my lady to hysterics" (Anashevich, 1997, p. 30). "Between Poznań and Kraków" means "somewhere in Poland", in the heart of Europe where the only script possible is to be killed during the war with no reason and purpose. Because of the never-ending repetitions of these two toponyms in different poems with a similar motif and topic, the imaginary geography of Poland in Anashevich's creative work is characterized by fragility and uncertainty, and functions as a "flickering cultural code" to be deciphered. In addition, in the poem What's under Jeanna's Dress; What's under Jeanna's Skin [To, chto u Zhanny pod plat'em; to, chto u Zhanny pod kozhej] the implicit image of the Baltic sea appears with a hint of the Polish-Lithuanian Commonwealth: "Their ark was sailing between Lithuania and Poland, on both sides whizbangs were flying, cannons were firing" (Anashevich, 1997, p. 29).

The main character of I Heard: An Actor from the Burnt-Down Theatre is a mummer with a lot of faces, but the same senseless "Great War" has a long-term impact on his regular life and one meaning of the theatre starts to prevail over the other (it burns it down in all senses) and makes him wander: "I move from war to war, between Jean and Jean. / Lights fall, firecrackers explode: all these are bad signs" (Anashevich, 2008). Jean as a commonplace but meaningful name for a philistine throughout Europe is supposed to be a milestone in geopoetics: the French "Jean" can be translated into Russian as Ivan or into Polish as Jan ${ }^{5}$. So, this wandering is rather concrete for every reader who is familiar with complex European culture with its common roots in Christianity.

Translated by Vitaly Chernetsky.

Furthermore, Anashevich called the heroine of What's under Jeanna's Dress; What's under Jeanna's Skin by a Polish variant - Joanna. 
Later, an actor from the analysed poem says:

If only they didn't throw me out of the train car, take me all the way to Poland or to some other place, as long as it's far away,

to a city with a large square where I could put my little theatre booth. (Anashevich, 2008)

The above quote indicates a possible reason for Anashevich to be interested in Poland: as a country of medieval market squares, either Poznań or Kraków (or any other historical Polish city) could become the scenery for street theatres and shelters for strollers, and be a personal heaven for any creative person: "I would stop running, become a holy fool, my handwriting would change" (Anashevich, 2008). If the Road is an allegory for human life and looking for oneself, Poland in Anashevich's poetry is a dead end, the Grand Finale of the show, the completion of searches, and, according to previous Soviet narratives, is a huge terrifying cemetery ${ }^{6}$ and a suitable place to die.

Finally, the author could have chosen Poland because of its mythopoeic nature and culture-producing potential emphasised by the Soviet underground of the 1970s. In addition to being a liminal space, the country was depicted as the underworld of Hades, so that the Vistula became the Styx in the poem Sailing by Elena Shvarts (Woroncowa, 2015); Anashevich's poetry features the same motifs of the one-way process of transgression from life to death. For instance, the author portrayed his characters as the walking dead, which is possible only in Poland:

The clown's sleeves have grown, his eyes have set, foam has come from his mouth. The naked clown is hard to recognize, a naked soldier is hard to remember, when they're going through the Polish fields with a copper bullet in the forehead. (Anashevich, 1997, p. 21)

In his essay Forms of Time and of the Chronotope in the Novel (1937-1938) Russian philosopher Mikhail Bakhtin introduced different types of "time space" models in literature and revealed the "threshold chronotope", among others. According to Bakhtin, it has peculiar emotionally valuable intensity and could be defined as the "crisis chronotope", or the "chronotope of life changes" (Bakhtin, 1986, p. 281). This model forms a part of the big carnival, mysterious chronotopes with an atmosphere of medieval culture

\footnotetext{
6 This definition was coined by Bazyli Białokozowicz as a metaphor for all the catastrophes experienced by Poland during the 20th century: two World Wars, the Warsaw Uprising, the Nazi concentration camps, Monte Cassino etc. (Białokozowicz, 1977, p. 22). Thus, there are complexes of texts about these events (e.g. David Samoylov's Close Countries, 1954-1959 [Blizhnie strany]) and also about the traumatic personal experience of Soviet soldiers in Russian-language literature (e.g. the iconic song Muscovites, 1953 [Moskvichi] by Evgenij Vinokurov). The heterotopian nature of Poland-cemetery united the two nations.
} 
with laughter, chaos, masks, puppets, and festivals in town squares even in very tragic situations like wars, revolutions or pandemics. Poland as the Borderland in Soviet, especially non-official, literature was considered to be a Great Threshold, and its transgression was connected to the existential choices and personal development of characters. Anashevich refers to this tradition and at the same time alters it significantly in accordance with new queer aesthetics, including strong elements of artifice. His lyrical subject is literally a part of the universal carnival that embodied all the principles of camp formulated by Susan Sontag: "Camp is a vision of the world in terms of style - but a particular kind of style. It is the love of the exaggerated, the "off", of things-being-what-they-are-not" (Sontag, 1964, p. 520). Anashevich's character is, to use Sontag's formulas, a woman in quotation marks, a man in women's dress, a drag queen with an almost female sensitivity, but only almost. Dmitry Sokolov comments: "A poet in Russia is no more than a poet, but less than a woman. So, my God, is Anashevich really the first Yaroslavna in Russian literature" (Sokolov, 1997, p. 33). His poems are thus a "Lament of Yaroslavna" who is artificial and disguised, and illustrates the camp convertibility of "man" and "woman" and the conventional and androgenic nature of this opposition.

In A Letter to Sonya B., Who Left and Never Returned [Pis'mo k Sone B., kotoraya uekhala i ne vernulas'] it is said:

I'm in love. His costumes:

Giselle,

a Japanese empress, a virgin bride. (Anashevich, 1997, p. 15)

Margarita Meklina claims that behind this bizarreness and the irony of Anashevich's characters is hidden true deep feeling (Meklina, 2002, p. 11). Sontag, to whom Meklina refers when analysing the poetry by the "Voronezh Kalderon", remarks about these examples that such a feeling is "dead serious" (Sontag, 1964, p. 525). Not by chance was Poland chosen as the setting for a new camp sensitivity in the post-Soviet world. By virtue of its traditionally romantic and tragic perception by a Russian-speaking recipient, Poland becomes a perfect artistic space for the embodiment of the complicated and linked concepts of Beauty, War, and Death. After all the catastrophes of the 20th century it is impossible to speak about traumatic experiences using the descriptive categories of realism, so Carnival turns into Camp, the Great Cemetery of Poland becomes the world of the walking dead, and the gender certainty of lyrical subjects mutates into a masculine character with feminine costumes and narratives. 


\section{Conclusion}

To sum up, Anashevich as an iconoclastic innovative author in the post-Soviet world masterfully exploits all the characteristics of Poland as a Borderland that used to be crucial in Soviet culture. Although for Russia this country no longer seems an important territory in the cultural dialogue with Europe, the poet uses the image of the Borderland and some traditional properties, such as: Poland as a front line; Poland as a cemetery; and Poland as a mythopoeic threshold. For Russian-speaking recipients, who are largely unfamiliar with the real geopolitical and cultural landscape of the country, thanks to Anashevich's creative work Poland becomes a liminal zone between real and artificial, alive and dead, natural and unnatural, where everything is possible and new types of characters can appear.

It is worth mentioning that in the post-Soviet world this country is no longer the boundary between Russia and Europe. Generally speaking, in Anashevich's poetry there is no Russia at all and Poland embodies the whole of European civilization, it is the quintessence of Medieval Europe itself, the most appropriate place and space for new theatrical camp reality.

\section{References}

Adel'geĭm, I. (2008). Neizbezhnost' liubvi. Inostrannaia literatura, 2008(8), 253-256. Anashevich, A. (1997). Stol'ko lovushek: Stikhi. Moskva: ARGO-Risk.

Anashevich, A. (2008). Russian poetry: Aleksandr Anashevich (V. Chernetsky, Trans.). Jacket, 36. Retrieved from http://jacketmagazine.com/36/rus-anashevich-trbchernetsky.shtml

Bakhtin, M. (1986). Formy vremeni i khronotopa v romane. In M. Bakhtin, Literaturnokriticheskie stat’i (pp. 121-290). Moskva: Khudozhestvennaia literatura.

Białokozowicz, B. (1977). Polska w poezji radzieckiej. In B. Białokozowicz (Ed.), Jak unieść wierszem Twoją chwałę: Polska w poezji radzieckiej. Łódź: Wydawnictwo Łództwo.

Brodskiĭ, I. (2000). Bol'shaia kniga interv'iu. Moskva: Zakharov.

Dashkevich, I. R. (1989). Bol'shaia granitsa Ukrainy (Ėtnicheskiı̌ bar'er ili ètnokontaktnaia zona). In E. M. Pospelov \& I. I. Krupnik (Eds.), Etnokontaktnye zony $v$ evropeǐskoŭ chasti SSSR (geografiia, dinamika, metody izucheniia) (pp. 7-21). Moskva: Moskovskiü filial Geograficheskogo obshchestva SSSR.

Kaganskiŭ, V. (2018). Russia et Polonia. Sem' iskusstv, 2018(3(96)). Retrieved from http://7i.7iskusstv.com/2018-nomer3-kagansky/

Kuzmin, D. (2007). Predislovie. Novoe Literaturnoe Obozrenie, 85. Retrieved from http://magazines.russ.ru/nlo/2007/85/ro22.html

Meklina, M. (2002). Plastmassovyı̆ korol', dama, poèt. In A. Anashevich, Fragmenty korolevstva (pp. 5-13). Moskva: Novoe Literaturnoe Obozrenie. 
Orlitskiŭ, I. B. (2017). Rifmennyı̆ (raeshnyŭ) stikh v noveřsheĭ russkoŭ poėzii. In A. M. Moldovan (Ed.), Proceedings of the V. V. Vinogradov Russian Language Institute, XI Slavic Verse (pp. 158-170). Moscow: Nestor-Istoria.

Polska-Rosja: Diagnoza społeczna. (2015). Warszawa: Centrum Polsko-Rosyjskiego Dialogu i Porozumienia.

Samoĭlov, D. (2000). Perebiraia nashi daty. Moskva: Vagrius.

Sokolov, D. (1997). Stikhi Aleksandra Anashevicha: Dva raza. In A. Anashevich, Stol'ko lovushek: Stikhi (pp. 33-34). Moskva: ARGO-Risk.

Sontag, S. (1964). Notes on “Camp”. Partisan Review, 31(4), 515-530.

Vorontsova, K. (2016). Pol'sha kak granitsa v poslevoennoŭ russkoŭ poèzii. In K. Wilusz (Ed.), Wschód-Zachód w nieprzerwanym dialogu (pp. 131-148). Słupsk: Wydawnictwo Naukowe Akademii Pomorskiej w Słupsku.

Woroncowa, K. (2015). Wizja kultury europejskiej w wierszu Jeleny Szwarc "Pływanie”. Źródła Humanistyki Europejskiej, 8, 91-101.

Zamiatin, D. N. (2003). Gumanitarnaia geografiia: Prostranstvo i iazyk geograficheskikh obrazov. Sankt-Peterburg: Aleteĭia.

Zorin, A. (2006). Za chto my ne liubim Ukrainu? Kommersant, 2006(12), p. 8.

\section{Польша как «большая граница» \\ в постсоветском мире: поэтический взгляд}

В данной статье анализируются устойчивые характеристики художественного пространства Польши, которая занимала позицию медиатора между Западом и СССР. Особое внимание уделяется механизмам репрезентации Польши как пограничной территории в свете катастроф XX века. С распадом Советского Союза изменились нарративы, однако главный концепт «Польша как Большая граница» всё ещё остаётся неизменным. Ориентируясь на традиционные элементы, поэзия в постсоветском мире использует новые инструменты, такие как Камп, чтобы адекватно отражать лиминальную и карнавальную природу страны. Стихи Александра Анашевича в данном контексте анализируются как яркий пример современного понимания многовековых межкультурных практик.

Ключевые слова: Польша, поэзия, исследование границ, Большая граница, Александр Анашевич, постмодерн, трансгрессия, Камп, Квир исследования. 


\section{Polska jako „Wielkie Pogranicze” w przestrzeni postradzieckiej: Poetycki punkt widzenia}

Artykuł ma na celu zbadanie cech przestrzeni kulturowej Polski, która swego czasu odbierana była jako ta, zajmująca pozycję mediatora pomiędzy Zachodem a ZSRR. W artykule przede wszystkim kładzie się nacisk na zbadanie mechanizmów reprezentacji Polski jako „Wielkiego Pogranicza” w świetle katastrof XX wieku. Od czasu rozpadu Związku Radzieckiego narracje uległy zmianie, ale koncepcja „Polski jako Wielkiego Pogranicza” nadal pozostaje aktualna. Choć poezja w przestrzeni postradzieckiej wciąż zwrócona jest przede wszystkim w stronę tradycyjnych dla niej form, to coraz częściej sięga ona po nowe estetyczne rozwiązania, takie jak np. Kamp, aby wskazać na liminalny i karnawałowy charakter polskiej przestrzeni kulturowej. Wiersze Aleksandra Anaszkiewicza są w artykule analizowane jako żywy przykład współczesnej percepcji tych wielowiekowych interkulturowych praktyk.

Słowa kluczowe: Polska, poezja, badania nad granicami, wielkie pogranicze, Aleksandr Anaszkiewicz, postmodernizm, transgresja, kamp, badania queer.

Przekład z języka rosyjskiego Katarzyna Roman-Rawska

\section{Note}

Kristina Vorontsova, PhD., Assistant Professor at the Department of English Literature and Culture, Institute of Linguistics and Literary Studies, Faculty of Humanities, University of Natural Sciences and Humanities in Siedlce, Siedlce.

kristina.vorontsova@uph.edu.pl

The preparation of the article was self-funded by the author.

No competing interests have been declared. 